\title{
Innovation and Entrepreneurship in Colleges: An Interpretive Study of the Piloting of Innovation Centres
}

\author{
CAROL L. MCWILLIAM*
}

\begin{abstract}
The implications of college involvement in innovation and entrepreneurship through centres which promote such directions have as yet received little consideration. This interpretive study examines the sociocultural context of Ontario Colleges at the macro, medial, and micro levels of the organization. Findings describe government fiscal policy, profitability motives, bureaucratic organizational norms, incrementalism, and political and power relationships impeding successful integration of innovation centres into colleges. Such factors have precluded consideration of several significant philosophical issues. Privatization of college education, the research, community service and teaching roles of colleges, and the socialization role which colleges might play in inculcating values and skills associated with innovation and entrepreneurship have yet to be examined. Clearly, if colleges are to achieve purposeful direction-setting for the future, all involved with this system must engage in interactive leadership to decide upon values, motives and educational philosophy related to innovation and entrepreneurship.
\end{abstract}

\section{RÉSUMÉ}

Jusqu'à présent le rôle que jouent les universités sur l'innovation et l'esprit d'entreprise au moyen des centres créés à cet effet n'a guère été analysé. Cette étude examine le contexte socioculturel qui caractérise les collèges postsecondaires ontariens à l'échelle macroéconomique, médiane et locale de leur organisation. Les résultats font apparattre les principaux aspects de la politique fiscale du gouvernement (recherche des profits, normes en matière d'organisation

*The author is a recent doctoral graduate of the Department of Educational Administration, The Ontario Institute for Studies in Education, and is currently employed as Assistant Professor, Centre for Studies in Family Medicine, The University of Western Ontario.

ACKNOWLEDGEMENTS:

Dr. E. Hickcox, Dr. R. Townsend, and Dr. R. Hayhoe who served as advisors for the doctoral research for this article, are acknowledged with appreciation. 
administrative, gradualisme) tout en soulignant le type de relation qu'il est souhaitable de voir s'instaurer entre pouvoir et politique pour que ces centres d'innovation s'intègrent avec succès dans les collèges. Cette analyse a permis de dissiper diverses ambiguités d'ordre philosophique. Il semble que la privatisation de l'enseignement supérieur, la recherche, les services à la communauté, le rôle éducatif des universités et enfin les échanges sociaux que la vie collégiale permet pourraient donner la chance aux universités de jouer un rôle déterminant dans la transmission des valeurs et des compétences indispensables à l'acquisition d'un esprit d' innovation ou d'entreprise mais ceci reste cependant à étudier. De toute évidence, si l'on veut que les universités soient les promotteurs efficaces de l'avenir, il faut que ceux qui cuvrent dans ce domaine se réunissent pour débattre des valeurs et du type de pédagogie susceptibles de rendre possible l'enseignement de l'esprit d'entreprise et d'innovation ainsi que des raisons de mettre en cuvre un tel enseignement.

As instruments of public policy, the Colleges of Applied Arts and Technology of Ontario in recent years have been called upon to use innovation to realize their technological and economic potential as educational institutions. Contract research, consulting, patenting, joint ventures, personnel exchanges, incubation of start-up companies, business advice to students and faculty wishing to commercialize products and processes, brokerage between post-secondary entrepreneurs and the private sector, marketing of the educational institution's resources to assist industry in product development, and technical services to industries all exemplify such innovation. Such activities entail entrepreneurship, for colleges undertaking this type of innovation assume control and some risk in generating land or materiel, labour, and/or capital from the private sector to underwrite operational costs. To date, these new thrusts have been pursued through new organizational units called "centres" for technology transfer, innovation, and entrepreneurship.

The Colleges of Applied Arts and Technology housed twelve innovation centres at the outset of this research. A variety of government, private sector and college budgets funded these centres. As a three-year experimental project begun in 1985 , the future of these centres came under review by government during the period of this research. In early December, 1988, the Ontario government discontinued support for the innovation centres. Centres for entrepreneurship, implemented in 1987 , have become the newest focus.

But the implications of such innovation and entrepreneurship for the college system have not received open consideration. Provincial government literature had described innovation centres as "providing an important infrastructural support in encouraging the creation of new employment, developing new products for domestic and international markets, and improving the technological capability of Ontario industry" (Ministry of Industry, Trade, and Technology, 1985). 
From the educator's perspective, new educational norms, values, and goals related to ingenuity, creativity, adaptability, risk-taking, and community service might emerge from this new focus. Faculty development and institutional prestige could prove to be valuable fringe benefits. On the other hand, educational institutions which have undertaken innovation through appended or decentralized units in the past have experienced isolation or termination of innovators (Dunbar et al., 1982, 106; Levine, 1980, 4), conflict (Ashby, 1974, 92; Nakamura, 1981, 113-133; Weatherley and Lipsky, 1977, 171-197), and impeded organizational change (Dunbar et al., 1982, 91-108; Levine, 1980,4). Such centres could also become a drain on educational resources, compete inappropriately with the private sector, hinder college progress toward other educational priorities, and create a negative image of the college in its community.

As educational leaders and decision-makers have little information on such potential outcomes, this research was undertaken to describe the socio-cultural context of innovation and entrepreneurship in the Colleges of Applied Arts and Technology of Ontario. Specifically, the compatibility of such innovation and entrepreneurship with traditional educational endeavours was studied, as was the profitability of such innovative and entrepreneurial endeavours to college education. An understanding of such implications of innovation and entrepreneurship could enhance future direction-setting decisions related to the mandate of this educational system.

\section{METHODOLOGY}

The framework for interpreting the socio-cultural context of innovation and entrepreneurship in the Colleges of Applied Arts and Technology combined three theoretical perspectives. These included conceptual models related to organizational innovation through appended units (Levine, 1980,11) and organizational purpose formulation (Hodgkinson, 1978, 41-44) and theory on levels of analysis of organizational culture (Dobbert, 1982, 56; Hage, 1980, 12). The conceptual framework guided analysis and interpretation of the subjective, valuational aspects motivating and shaping the pursuit of innovation and entrepreneurship, or of alternative goals and directions, in the colleges studied. Additionally, the framework focused attention on the interaction patterns, or network-building effort centred on creating, adopting, and sustaining implementation of innovation and entrepreneurship.

The study included three purposefully selected colleges. One college, with an institutional saga suggesting a reputation of success in innovation, was studied in depth. Two colleges with differing size, complexity, demographics, and geographical regions furnished data to determine any comparability or transferability of findings to other Colleges of Applied Arts and Technology. Medial (or organizational level) analysis at each of these institutions included extensive document and minute review to delineate group value-motivational behaviour and interaction patterns related to both innovation centres and the colleges as 
organizational entities. At the college studied in depth, over forty hours of participatory observation of board, administrative, academic council, faculty, and program advisory meetings also provided data for this medial analysis.

A total of eighty-seven confidential interviews, each approximately one hour in length, comprised the micro-analysis, or study of individuals, within these three organizations. The purposive sampling approach sought out individuals representative of a wide cross-section of academic divisions and all levels of academic administrative staff as well as faculty. In total, eight college and innovation centre board members, thirty-three administrators representing all four levels of academic administration and the innovation centre, and thirty-nine faculty from twenty-seven different programs provided interview data at the primary college studied. Seven administrators acted as key informants at the other two colleges studied.

The purposive sample also encompassed chain sampling strategies. When interviewees spoke of specific college employees known to them as having been involved in any type of innovative or entrepreneurial projects, these employees were subsequently sought out as interviewees who were most likely to be knowledgeable about any activities related to innovation and entrepreneurship at the college.

Extensive document review, a limited amount of participatory observation, and six interviews with key government elites furnished data for the macro-analysis, or interpretation of the college system's socio-cultural environment. The latter encompassed both federal and provincial governments and representatives of the external college community.

A semi-structured interview schedule contained twenty-four questions. Developed from the conceptual framework, questions one through eleven sought an understanding of the individual's perceptions of his or her own value-motivational behaviour within the college context. Questions twelve through twenty-two assessed the individual's level of involvement with the innovation centre, to provide an indication of specific value-motivational behaviour related to the centre. Hall and Louck's typology of levels of use of an innovation (Sorg, 1983, 391-406) provided the theoretical basis for these questions. Question twentythree sought the interviewee's perceptions about the power and political relationships associated with the college's operation of its innovation centre. Finally, question twenty-four ensured refinement of understanding in the mutual construction of reality through summarization and clarification of the interviewee's perceptions (Appendix A).

\section{RESULTS}

Many contractual factors have contributed to the challenge of implementing innovation and entrepreneurship through innovation centres in Ontario colleges. At the macro or extra-organizational level, federal and provincial government policy directions have fostered innovation and entrepreneurship in response to 
social, political, and economic forces. Simultaneously, however, the provincial government has impeded college innovation and entrepreneurship by restricting regulations, ignoring privatization issues, and leaving college leaders to sort out conflicting social values at the local level.

At the medial or group level, within the colleges themselves innovative and entrepreneurial pursuits existed prior to the piloting of the innovation centres. Such efforts continued despite fiscal constraints, hierarchical, bureaucratic decision-making, uncoordinated, fragmented operations, and conflicting values. Ultimately, however, innovative and entrepreneurial efforts suffered severe compromise.

At the micro level, individuals within the colleges contributed to this phenomenon through pursuit of diverse goals, without due consideration of various directions. Furthermore, although individuals recognized the many impediments to organizational pursuit of commonly shared purposes, most expected those in positions of power to determine and achieve direction for them. The following sections describe this enactment of innovation and entrepreneurship.

\section{Government Incentives}

Government values and motives in the evolution of this direction toward innovation and entrepreneurship have not been particularly subtle. The 1988 federal policy on entrepreneurship (Industry, Science, and Technology Canada, 1988 , 3) clearly stated government intent to mobilize entrepreneurship for the economic, social, and cultural development of Canada through partnerships with the academic community. Policy actions included entrepreneurship studies, skills training, and access to science and technology for entrepreneurs wishing to develop and commercialize innovations.

Likewise, as early as 1984, the Ontario government stated a desire to promote the ability to invent, to create, and to be entrepreneurial, and stressed that "universities and colleges ... must be full partners in the economic and social transformation of the province (Grossman, 1984, 1). A 1986 budget statement reinforced this direction, citing the priority of cooperation with post-secondary schools "that demonstrate effectiveness in basic research and success in securing commercial contracts in applied research" (Shore, 1986, 8). Most recently, the report of the Premier's Council on Technology (Volume I, 1988, 233), which directs a one billion dollar technology fund to encourage science and technology research in both private sector and post-secondary institutions, has indicated this Council's intention to study related education and training initiatives.

But government fiscal policy has played an even greater, although more subtle, role in promoting college involvement in innovation and entrepreneurship. Until 1985 , the federal government had purchased training provided by colleges through the provincial governments. But in 1985, the federal government's Canadian Job Strategies Program introduced two major fiscal policy changes: decreased federal funding for vocational training; and purchase of a portion of the training through 
funding the private sector to meet its own training needs. These changes have become increasingly significant, for the 1986-87 Canada-Ontario Agreement on Training specified an annual increase in this new purchase approach. The direction has forced colleges to be entrepreneurial, for now these institutions have to compete with private sector training agencies for funds to deliver training programs.

The provincial government's creation of a new Ministry of Skills Development in 1986 to administer funds and decisions for federal training purchases still directed through the provincial government has exacerbated this push toward college entrepreneurship. This new ministry has secured training from many sources other than the colleges. Thus, this too has forced colleges to compete with the private sector for provincial funding from a ministry not accountable for them. The change has had a major impact on colleges, for approximately $33 \%$ of college funding now comes through the Ministry of Skills Development, rather than from the Ministry of Colleges and Universities.

In 1988, the federal government froze its apprenticeship budget for Ontario at the 1987 figure of $\$ 37$ million, despite growing demand for training. Colleges faced even more pressure to compensate for underfunding through entrepreneurship. Provincial government funding approaches have not offset this pressure. Increased funding for innovation has been largely directed toward universities and Ryerson Polytechnic Institute through the University Research Incentive Fund, the University Excellence Fund, and funding of university-based technology transfer centres.

Access to Ontario's three-year Innovation Centre Program funding begun in 1985 therefore merely constituted the first direct government incentive for innovation and entrepreneurship by colleges. Although this program was terminated in 1988, its successors, centres for entrepreneurship, funded by a combination of government and private sector moneys, have continued government encouragement of similar college activity. Such government policy implemented through the power of both Progressive Conservative and Liberal parties, appears to send a very clear message motivating college innovation and entrepreneurship.

\section{Government Impediments}

Despite such incentives, government impediments to innovation and entrepreneurship by colleges also have existed. First, the Ontario Council of Regents, responsible for providing policy advice on college education to the Minister of Colleges and Universities, had absolutely no involvement in decisions to establish centres for innovation and entrepreneurship in colleges. In fact, even the Ministry of Colleges and Universities only became involved after innovation centres had been established in 12 colleges and 10 universities with funding and contractual arrangements by the provincial government's Ministry of Industry, Trade, and Technology. As a consequence, the Ministry of Industry, Trade, and Technology 
determined the initial policy direction - to use the wealth of research activity and resources available in Ontario's post-secondary institutions to create new employment, develop new products and markets, and to improve the technological capability of Ontario industry. From the start, the appropriateness of this direction for publicly funded colleges went unexamined.

Once the Ministry of Colleges and Universities did become involved, mixed messages impeded college evolution of a role in innovation and entrepreneurship. While the Ministry of Colleges and Universities created a Department of Commercial Services in its College Affairs Branch in 1987, sending a message of support for innovation and entrepreneurship, this ministry also has conveyed many messages of non-support.

For example, in reaction to private sector concerns about competition from publicly funded college innovation centres in the business marketplace, the Ministry of Colleges and Universities blocked college revenue generation through incorporation of innovation centres. As colleges were obliged contractually to match government funds for operating innovation centres, in cash or in kind, this action constituted a serious constraint. Furthermore, other college entrepreneurial initiatives, including testimonial advertising and fund-raising, met with reactive Ministry of Colleges and Universities policy initially banning, and later restricting, such activities.

Secondly, no initiative to create leadership in addressing the sensitive, value-laden issues related to private sector funding and involvement in college education has as yet materialized in the government structures responsible for the college system. The Ontario Council of Regents' new mission statement emphasizes this group's intention to provide leadership in the process of defining, rather than in the ultimate defining of the purpose of college education. Despite repeated pleas in college-prepared annual reports for government direction about college mandate, the Ministry of Colleges and Universities has also opted out of active determination of college mandate with regard to innovation and entrepreneurship. Representatives of this department indicated that while direction toward innovation and entrepreneurship comes from the Cabinet, throne speeches, and the Premier's Council on Technology, goals have been left open, so that colleges are free to evolve, and move around, and develop their own goals. Only time and the possibility that colleges might exercise self-determination will determine whether such potentially inflammatory issues as the trend toward privatization of college education will receive open consideration through government-initiated policy processes.

Confronted with an opportunity to participate in policy evolution on such issues, college administrators and educators have other environmental circumstances to consider. Current socio-demographic factors, including a declining immediate post-secondary applicant pool and skilled labour force, motivate a re-examination of traditional college goals and directions. National and provincial economic factors and increasing international competition exert pressure for more integration of educational with social and economic policy evolution. Cries for increased 
accountability of colleges as instruments of public policy reinforce this direction. Mass media repeatedly support the notion that innovation and entrepreneurship have arrived as Canadian social ideals.

Simultaneously, at the grassroots level, however, these same educational leaders grapple with advice put forward by college governors and program advisors representing their local communities. These groups still attend largely to more traditional academic goals and processes. Indeed, those studied in this research displayed no interest in college involvement in innovation through applied research and technology transfer. Furthermore, very limited interest in education for entrepreneurship appeared. Primarily, interest in entrepreneurship stemmed from recognition of the need for dollar profits to ensure program or institutional survival in an era of government-imposed economic constraint. Thus, even individual reflection of the extra-organizational environment of colleges with regard to innovation and entrepreneurship portrayed motives and values largely premised on dollar profit. Few considered the potential compatibility or incompatibility amongst norms, values, and goals of innovation centres and those related traditionally to college education.

\section{The Intra-Organizational Context of Colleges}

Collective activity within the colleges studied reflected similarly limited concern about the compatibility of innovation and entrepreneurship with traditional college education. Prior to acquisition of innovation centres, two of the three colleges studied had proactive units pursuing similar innovation, including research and development of computer software, interactive video, and telecommunication materials for educational delivery. Through annual reports, the decision-makers of one of these two institutions openly declared that such innovative efforts were intended to make the college less dependent upon government grants. Entrepreneurship was no secret.

Such activity would suggest that innovation and entrepreneurship as proposed for innovation centres would not be incompatible with organizational norms, values, and goals. In fact, incompatibility did not appear to be an issue. Where such innovative and entrepreneurial activity occurred, these pursuits transpired despite official college statements largely endorsing traditional training goals.

More amazingly, innovation occurred despite day-to-day preoccupation with process-related goals emphasizing efficiency and productivity rather than any academic, innovative, or entrepreneurial directions. In reality, the impediments experienced by all three colleges studied forced each organization to concentrate on negotiating and delivering training programs and on managing physical, fiscal, and human resources. Inadequate government funding, government approaches to funding, government-dictated operating policies, and the absence of government and college educational philosophy, policy, and leadership contributed significantly to this organizational orientation. Fiscal policy decided direction. 
Furthermore, the bureaucratic structure and functioning of colleges as a sub-set of a bureaucratic government prohibited refinement of organizational purposes. Formal hierarchy, formal communication channels, authority relations, rules and regulations, and centralized formal decision-making meant that the power wielded emanated from those in positions of authority. These key decision-makers determined the values and motives associated with innovation centres.

In the instance of the most entrepreneurial college, key decision-makers acquired an innovation centre to achieve monetary profit for the college. Non-fulfilment of that motive understandably became the reason for the centre's termination. In the other two colleges, key decision-makers determined community service to be of general profitability to the organization's image. Fulfilment of this motive contributed to greater hesitancy on the part of key decisionmakers in each of these two institutions to terminate the innovation centres, despite the Ministry of Industry, Trade, and Technology's decision to do so. Ultimately, however, the position power of this ministry effected the termination of these two innovation centres as well. These colleges simply could not afford to continue their centres without government funding and support. Centralized authority therefore determined college direction.

Bureaucratic structure and functioning also ensured a segmentalist (Baldridge and Burnham, 1975, 169-170; Kanter, 1983, 20) approach between and among various groups constituting these organizations. Poorly executed communication and collaboration linkages ensured that innovative efforts most often went unlinked with opportunities for meaningful exploitation of them. Energy therefore remained unfocused, for such operational norms precluded reflection on valuational, philosophical, and mission-related issues. Mutual understanding of purpose (Vaill, 1984, 88-89) and mutual adaptation toward a purpose (Berman and McLaughlin, 1976, 360) did not transpire. In the absence of mutually shared purposes, priority-setting frequently emerged reactively from political and power relationships enacted in competition for scarce resources. Decisions implemented therefore reflected incremental changes in what already was, or had been, rather than any breakaway innovation, even as this might have related to academic endeavours.

To complicate matters further, at the one college studied in depth, groups consistently struggled with the simultaneous valuing of autonomy and collaboration. The diversity of professionals comprising the educational institution contributed to a loosely coupled organizational existence in which individual autonomy was valued. Nevertheless, a felt need to achieve some semblance of collegiality clearly existed. Efforts to satisfy each of these opposing values only frustrated group pursuit and fulfilment of the other. As a result, all groups became further caught up in attending to processes to promote autonomy or collegiality. Such activity prevented attention to purpose, mission, or even short-term objectives, be these related to traditional academic pursuits or to innovation and entrepreneurship. 
Organized work effort thus did not reflect Hodgkinson's $(1978,40)$ organizational purpose formulation. Rather, the state of organization existing in the college studied in depth more closely approximated Greenfield's (1984, 164-165) antileadership phenomenon. The social order was pluralistic, and the positiondesignated leaders determined, rather than represented, the values of the group. While key individuals at the other two colleges studied made an effort to predetermine and act on values, and consequently minimized organizational conflict, lack of similar effort at the ministry level thwarted innovation centre continuation at these institutions. Innovative, entrepreneurial, and, indeed, traditional academic pursuits evolved through incrementalism and the power relationships enacted, not by purposive action premised upon any vision of the future.

\section{Individual Enactment of College Activities}

Value-motivational behaviour at the micro or individual level of the organization also shaped this intra-organizational context of innovation and entrepreneurship. Consistent with previous research findings (Konrad and McNeal, 1984, 31-40; Piccinin and Joly, 1978; Quinn, 1972), individuals held a great diversity of goals. Many identified traditional academic goals. These included: providing education for employment and life skills; promoting educational accessibility and mobility for students; and occasionally, providing a service to the community. Less frequently, individuals reflected the valuing of innovation as part of academic goals, primarily in conjunction with the development of new curricula and instructional delivery modes.

Very few cited goals related to innovation through research and development. Goals related to entrepreneurship appeared somewhat more frequently, but these goals related to promoting student recruitment and retention, enrolment growth, and revenue generation for the individual's program, division, school, and college. Profit to the institution and, both directly and indirectly, to one's self, provided the incentive. Individuals pursued linkages and partnerships with business, improved college marketing, and college survival, and often spoke only of personal profit motives.

Individuals spoke as frequently of personal goals related to organizational operation. People at all levels of the college studied in depth spoke of desire and effort to improve communication, effect collegiality, promote human resource development, and contribute to the development of a college mission, goals, and strategic plan. Good will certainly prevailed amongst individuals, even though collective action did not reflect successful achievement of the apparently desired outcomes.

Most cited the nature of the organization, its operation, and the work opportunities afforded as ample incentive for their commitment to these goals. Only a few individuals cited innovation-related incentives, including the opportunity to be involved in innovation, research and development projects, and the 
college's progressiveness. Likewise, a few individuals also referred to entrepreneurial incentives, voicing appreciation of the opportunity for college employees to pursue their own businesses, consultant work, or other private entrepreneurial endeavours. None portrayed altruistic opposition to the existence of incentives and goals related to innovation and entrepreneurship in the colleges studied. A limited few did allude to the potential detrimental effects such directions could have on the pursuit of educational values and goals.

Impediments observed at the organizational and group level affected individuals similarly. Individuals frequently spoke of inadequate resources, particularly fiscal resources, and several related concern about organizational focus on budget rather than on teaching students.

However, much greater concern emanated from perceptions about poor administrative and organizational structures, and poor communication impeding goal pursuit. Individuals bemoaned limited strategic planning, absence of a clear college mission, role, and mandate, lack of educational leadership, centralized decision-making and control, a "pigeonholing structure", lack of linkages between committees, polarized and competing factions, and incongruence between stated and enacted philosophy.

Several explained how lack of clarity in the organization's role, a conservative, rigid, and inflexible bureaucratic approach, and mixed messages about profit motives and the acceptability of revenue generation all combined to create confusion and scepticism about the college's innovation centre. In fact, $24 \%$ of the faculty interviewed at the primary college studied had never heard of this institution's innovation centre. An additional $70 \%$ of interviewed faculty, $55 \%$ of interviewed administrators, and $63 \%$ of interviewed governors reported that they knew of the centre's existence, but did not know anything more about it. Several readily admitted that they also had not attempted to acquire such information. Indeed, a few individuals engaged in innovative and entrepreneurial projects expressed distrust of using such a centre's assistance. They feared sabotage of both their own ideas and potential economic gains by such organizational structures.

Given such impediments and the diversity of individual goals, work effort, not surprisingly, also tended to be very individualistic. Individuals described work effort characteristic of traditional instructional delivery in a post-secondary milieu. Additionally, considerable effort focused on operational processes, particularly to effect improved communication and linkages within the college and its external environment. Work effort of an innovative nature reflected traditional academic undertakings such as innovation in curriculum delivery and design much more than it approximated the business-related research and development work undertaken by individuals in innovation centres. Fully one-third of individuals interviewed, however, indicated that they were also working on their own private business, consulting, or other outside contract work. Although this work effort clearly had not been harnessed for organizational purposes, such entrepreneurial endeavours closely approximated the work effort associated with innovation centres. 
Thus, the context of innovation and entrepreneurship enacted at the micro-level of the organization also could not be characterized as reflecting any clear incompatibility of norms, values, and goals. Rather, individuals who held key intra-organizational positions, particularly college presidents, determined the goals, values, and motives associated with college pursuit of innovation and entrepreneurship. Furthermore, the work effort of these key individuals also determined whether other individuals within their colleges and their respective innovation centres developed any semblance of mutual understanding and adaptation toward organizational involvement in innovation and entrepreneurship.

The vast majority of individuals within the college studied in-depth adopted a reactive stance to all organizational directions, including that of innovation and entrepreneurship. A "live and let live" philosophy prevailed. Most individuals communicated an expectation that those in positions of power should provide them with organizational information, a mission, a plan, and direction for its pursuit.

\section{DISCUSSION}

The context of innovation and entrepreneurship in the Colleges of Applied Arts and Technology as created by research participants in this study may be characterized as serendipitous and non-directional. No individual, group, or organization associated with the governments responsible for public education and only a select few individuals within the colleges studied even indirectly considered the appropriateness, purpose, and potential outcomes of college involvement in innovation and entrepreneurship through innovation centres. In fact, only one of the three colleges studied had begun to evolve the purpose and future direction of the educational role of the institution in a strategic plan. At all levels of the organization, including the macro or extra-organizational level, individuals and groups just busily pursued daily operational processes, be these related to innovation, entrepreneurship, or academic program delivery. Compatibility of norms, values, and goals associated with innovation and entrepreneurship and with college academic pursuits therefore has not been of concern.

\section{The Extra-Organizational Context}

As the issue of innovation and entrepreneurship within the colleges as publicly funded institutions of higher education has only recently surfaced, there has been little time to grapple with the complexities of related policy inquiry. Government has to date left this task to higher education itself. The extra-organizational context contains three critical points for decision-makers within post-secondary educational institutions.

First, money frequently dictates action. Impediments and incentives often are monetary in nature. Thus, circumstances foster dollar profit motives in association with college enactment of innovation and entrepreneurship. Value-motivational issues related to privatization of education therefore ultimately come into play, whether or not such issues are openly addressed. 
Secondly, the enactment of the political process inevitably shapes valuemotivational behaviour beyond any simply conceived or articulated norms, values, and goals, however well intended. Government responds to the society it represents (Millett, 1974, 143). Sheer numbers prevent government's effecting the one to one interaction, or participatory democracy, necessary to detail a vision from shared collective insights. Forthright detailing of a vision by key decisionmakers takes on the appearance of paternalism at best, and dictatorship, at worst. Furthermore, Canadians have not been perceived to possess the futuristic vision and risk-taking attributes (Kerwin, 1989, A7; White, 1988, xxi) necessary for innovation and entrepreneurship. Whether this perception represents fact or socially constructed myth, agents of government who proactively pursue uncertain futuristic vision run the risk of perceived radicalism.

Such phenomena force a reactive mode amongst government agents. Both the politics of staying in power and the power of being political combine to upstage the visionary component necessary for innovation and entrepreneurship. Education and its delivery as a public service has not escaped this fate. Consequently, the extra-organizational context of innovation and entrepreneurship cannot be either readily or rationally confirmed at any one time or place.

This circumstance creates both the opportunity and the responsibility for the conscious exercise of value judgements by decision-makers at all levels of the policy-making chain. But from the elected representative down through the hierarchy of government's ministries and, subsequently, through the hierarchy of those who are ultimately government employees within colleges, all must weigh the consequences of boat-rocking innovation. For the majority, very real and human basic needs for security shape action. Thus, politics determine plans, and plans represent reactive linear incrementalism (Braybrooke and Lindblom, 1963), not the futuristic vision associated with innovation and entrepreneurship.

Thirdly, no clear mandate has been articulated for the colleges. Much of the direction-setting is subject to influence power. The power of influence rests with its recipient. Thus, educators have a tremendous amount of reciprocal power to wield, should they so choose, in determining future direction related to innovation and entrepreneurship in the CAATs.

\section{The Intra-Organizational Context}

But the intra-organizational context of the college system also presents many challenges inhibiting innovation and entrepreneurship. The fragmented, bureaucratic nature of colleges leaves key decision-makers, and indeed, all educators, isolated, each forced to tackle such issues from his own perspective, or quietly to ignore them.

The comfort of quiet has most frequently prevailed. From the perspective of the vast majority of educators in the educational institutions studied, no clear incompatibility of norms, values, and goals existed between innovation centre operation and the more traditional academic undertakings of colleges. However, in the one college studied in depth, only a minority of college employees had any 
real grasp of the mandate of such centres. Where such understanding existed, the loosely coupled nature of post-secondary institutions (Weick, 1983, 15-37), goal diversity, and conflict avoidance behaviours precluded awareness of valuemotivational incompatibilities. Organizational mission and purpose with regard to innovation and entrepreneurship simply has not received consideration.

While silence on this issue has undoubtedly protected institutional peace, silence has also prevented active decision-making related to maximizing invaluable human resource potential. Given that maximizing human resource potential constitutes the primary business of education, this matter warrants serious consideration.

The valuing of privatization clearly emerges in current government socioeconomic policy, including the quasi-policy associated with innovation and entrepreneurship in higher education. But the legitimacy of intentional privatization in colleges has yet to be determined. Many recognize colleges as institutions serving those who could not be accommodated either financially or academically by universities. These individuals oppose the privatization direction, which they believe increases the discrepancy between educational services provided to the rich and those provided to the poor. Others applaud privatization as increasing the freedom of choice of individuals in pursuing higher education. In their view, such freedom of choice promotes excellence, accountability, and diversification of educational services. The value conflict related to these two perspectives will eventually surface, regardless of the direction taken in relation to innovation and entrepreneurship in the colleges.

Many related value-laden policy questions also have yet to be answered. Do the values associated with innovation, entrepreneurship, and privatization reflect those of Canadians? Do colleges as instruments of public policy have a role to play in inculcating such values in learners, thereby contributing to Canadian acculturation? Indeed, for what purposes, means or ends, does the government and, ultimately, the populace of Ontario, value colleges?

The picture may be interpreted more readily from what was not found amongst the data of this research. Only two of three innovation centre directors and eight educators of the 87 individuals interviewed alluded to the value of exposing the student populace of colleges to opportunities for innovation and entrepreneurship. These individuals believed such learning experiences would foster creativity, initiative, and critical thinking and problem-solving skills, and ultimately, the ability to earn a living through one's own unique abilities, independent of existing employment structures. The vast majority reflected a pattern of value-motivational behaviour locked into traditional teaching and learning activities and outcomes conforming to currently existing employment opportunities and expectations. While these individuals espoused the valuing of innovation and entrepreneurship, they related this valuing to their own personal endeavours and self-profitability, or to an organizational service to business, industry, and the community's few innovators and entrepreneurs who require assistance to achieve success. 


\section{CONCLUSION}

Educational leaders associated with the college system have not actively considered the educational implications of innovation and entrepreneurship through endeavours such as innovation centres. New learners, new approaches to educational delivery, new involvement in expanded scholarly roles for faculty, new educational goals related to the cultivation of life-long learning in society, and a renewed regard from their contribution to enhancing the nation's human potential could await colleges. Alternatively, pursuit of innovation and entrepreneurship might lead to yet more competition for increasingly scarce resources, decline of academic standards, misdirection of the human resource potential of educators, and perhaps even the decline of society resulting from the inculcation of avarice through educational processes.

This picture conveys greater meaning when placed in its broader context. Society currently experiences unprecedented change, which stems not least of all from a transition to a global economy. Several leading theorists have emphasized the imperative of innovation in recent publications (Drucker, 1985, 177; Gallagher, 1987, 9; Kanter, 1983, 354). In an age when innovation, technology, and knowledge are the basis of wealth, Canada lags far behind (Premier's Council on Technology, 1988, 20). For a decade, Canada has made about half the effort of its competitors in research and development (Kerwin, March 3, 1989, A7).

The time has come for educational leaders to consider the educational system's services and products with regard to innovation and entrepreneurship. Society expects publicly funded education to contribute positively to social change through economic and technological development, and both to reflect and to perpetuate its culture (Dale, 1982, 127-147). Educators have a key role to play, not only in providing technological and scientific knowledge and training, but also in shaping society's values and skills related to innovation and entrepreneurship.

To date, action premised upon good intentions, focused on daily operational processes, and unaccompanied by reflection about values, a vision, and mutual adaptation toward its pursuit has thwarted innovation and entrepreneurship. If innovation and entrepreneurship are to be successfully pursued in the Colleges of Applied Arts and Technology, then structural-functional impediments associated with bureaucracy and with organizational politics must be addressed. Most importantly, however, an interactive leadership process with conscious attention to valuational issues and mutual understanding of and adaptation to a common purpose must transpire. Such leadership can only happen if and when educational practitioners, policy-makers, decision-makers, and all others involved at all levels of the college system and the government responsible for it exercise their opportunity and responsibility for self-determination. Leadership of this nature requires that all become engaged in more thought prior to action. 


\section{REFERENCES}

Ashby, E. (1984). Adapting Universities to a Technological Society. San Francisco: Jossey-Bass.

Baldridge, J. and Burnham, R. (1975). "Organizational Innovation: Individual, Organizational, and Environmental Impacts". Administrative Science Quarterly, 20(2): 165-176.

Berman, P. and McLaughlin, M. (1976). "Implementation of Educational Innovation". Educational Forum, 40(3): 345-370.

Braybrooke, D. and Lindblom, C. (1963). A Strategy for Decision. New York: The Free Press.

Dale, R. (1982). Education and the Capitalist State: Contributions and Contradictions. In Cultural and Economic Reproduction in Education: Essays on Class, Ideology, and the State, ed. M. Apple, 127-147. London: Routledge and Kegan Paul.

Dobbert, M. (1982). Ethnographic Research: Theory and Application for Modern Schools and Societies. New York: Praeger.

Drucker, P. (1985). Innovation and Entrepreneurship: Practice and Principles., New York: Harper and Row.

Dunbar, R., Dutton, J., and Torbert, W. (1982). "Crossing Mother: Ideological Constraints on Organizational Improvements." Journal of Management Studies, 19(1): 91-108.

Gallagher, P. (1987). "The National Forum - What Legacy?" The Canadian Journal of Higher Education, 17(3): 3-9.

Greenfield, T. (1984). "Leaders and Schools: Willfulness and Nonnatural Order in Organizations". In Leadership and Organizational Culture, ed. T. Sergiovanni and J. Corbally, 142-169. Chicago: University of Illinois.

Grossman, Honourable L. (1984). Ontario Budget. Toronto: Ministry of Treasury and Economics Fiscal Policy Division.

Habermas, S. (1971). Knowledge and Human Interests. Toronto: Saunders.

Hage, J. (1980). Theories of Organizations: Form, Process, and Transformation. Toronto: John Wiley \& Sons.

Hodgkinson, C. (1978). Towards a Philosophy of Administration. London: Billing \& Sons.

Kanter, R. (1983). The Change Masters. New York: Simon and Schuster.

Kerwin, L. (1989). "Rating Canada's Innovation Quotient". The Globe and Mail. Friday, March 3, 1989.

Konrad, A. and McNeal, J. (1984). "Goals in Canadian Universities". The Canadian Journal of Higher Education, 14(1): 31-40.

LeCompte, M. and Goetz, J. (1982). "Problems of Reliability and Validity in Ethnographic Research." Review of Educational Research, 52(1): 31-60.

Levine, A. (1980). Why Innovation Fails. Albany: State University of New York Press.

Millett, J. (1974). Politics and Higher Education. Alabama: University of Alabama.

Nakamura, R. (1981). "Strategies for Defining Policy During Implementation." In Research in Public Policy Analysis and Management: Basic Theory, Methods, and Perspectives, ed. J. Crecine, 113-133. Greenwich, Connecticut: JAI Press.

Piccinin, S. and Joly, J.M. (1978). "The Goals of the University of Ottawa: What They Are and What They Should Be: Perceptions of Professors, Students, and Administrators." Ottawa: University of Ottawa.

Premier's Council on Technology. (1988). Competing in the New Global Economy: Report of the Premier's Council. Volume 1. Toronto: Ministry of Industry, Trade, and Technology.

Shore, V. (June-July, 1986). "Governments setting Up Special Funds." University Affairs: 7-8.

Sorg, J. (1983). "A Typology of Implementation Behaviours of Street-Level Bureaucrats". Policy Studies Review, 2(3): 391-406.

Vaill, P. (1984). "The Purposing of High-Performing Systems." In Leadership and Organizational Culture, ed. T. Sergiovanni and J. Corbally, 85-101. Chicago: University of Illinois.

Weatherley, R. and Lipsky, M. (1977). "Street-Level Bureaucrats and Institutional Innovation: Implementing Special-Education Reform" Harvard Educational Review, 47(2): 171-197. 
Weick, K. (1983). "Educational Organizations as Loosely Coupled Systems". In The Dynamics of Organizational Change in Education, ed. J. Baldridge and T. Deal, 15-38. Berkeley, California: McCutchan.

White, J. (1988). Intrapreneuring: The Secrets of Corporate Success in Canada. Markham, Ontario: Penguin Books.

\section{APPENDIX A}

\section{GUIDELINE FOR \\ INTERVIEW OF INDIVIDUALS WITHIN COLLEGE A}

1. What goals are you pursuing for College at the current time?

2. What goals do you think you will be pursuing on behalf of College in the next 5 to 10 years?

(If there is no clear indication of purely educational goals, ask specifically what these are and might be.)

3. What incentives motivate you toward the achievement of these goals?

*4. What are your employment-related aspirations?

5. What impediments have stood in the way of achieving the goals you have been pursuing on behalf of the college to date? (Explore personal, social, organizational, cultural, physical, economic, technical, time, and space impediments.)

6. What impediments do you anticipate may exist in the future?

7. What organizational structures have you used, if any, to make a systematic effort to achieve the goals you have identified?

8. What specific tasks, if any, have you undertaken to make a systematic effort to achieve these goals?

9. What specific technology, if any, have you adopted to make a systematic effort to achieve these goals?

10. What norms and values guide your work effort? (Use prods, with examples observed, as necessary. If necessary, focus in on education-related norms and values.)

11. Do innovation and entrepreneurship tie into your work-related goals now? In the future? If so, how?

12. Have you heard anything about the college's Innovation Centre? What have you heard?

13. (If not, or if minimal knowledge), have you taken any action to gain more information about the college's Innovation Centre?

14. What role, if any, did you play in its inception? For what purpose? How frequently? Over how long a period? (Ask when, if appropriate, so that minutes can be researched if not already uncovered.)

15. What do you think the goals of the Innovation Centre are? What should they be? 
16. Have you thought about, asked about, and/or discussed formally and/or informally the fit of the norms, values, and goals of this centre with those of your college? (Clarify with: Are they compatible?; Of what benefit is the Innovation Centre to your college?)

17. Have you been involved in further development of the Innovation Centre?

18. Should/would you get involved in the Innovation Centre? If so, in what way?

19. Have you thought about how the Innovation Centre, its use, or its effect on the college and/or its community could be improved?

20. Have you sought user feedback in order to improve the Innovation Centre?

21. Have you done anything to improve the Innovation Centre? If so, describe what has been done.

22. What does the future hold for the Innovation Centre at College? (Will the centre be modified to achieve an increased impact on clients, or to achieve new goals for the college, or what?)

23. Who has the power to effect any such change? Have you had any influence over such directions? If so, describe. If not, is there a way in which you might gain such influence?

24. Discuss the researcher's observations of the individual's value-motivational behaviour and level of involvement in the Innovation Centre, premised upon participatory observation and the interview itself. Clarify perceptions through interaction.

\section{Alternate questioning in lieu of questions \#11 and \#12 for selected interviewees at Colleges $B$ and $C$ :}

What motivated your college to have an Innovation Centre?

How does your Innovation Centre tie in with the norms, values, and goals of your college, or does it? Have you done anything in particular to assist tying in of the centre with the rest of the college?

Are your college's academic employees aware of the Innovation Centre? If so, what is the extent of their involvement with it?

*This question was deleted from the interview schedule early in the data gathering process, as respondents demonstrated discomfort in answering it. 